dr Wtdzimierz Stawecki, prof. IPS

Instytut Pojazdów Szynowych ,TABOR”

dr hab. Agnieszka Merkisz-Guranowska, prof. PP

Politechnika Poznańska

dr inz. Maciej Andrzejewski

dr inz. Pawel Daszkiewicz

Instytut Pojazdów Szynowych ,TABOR”

\title{
The use of alternative fuels in railway vehicles
}

In recent years there has been a significant increase in world population, thus there is a growing demand for transport. To meet this demand it is necessary to the sustainable development of the transport so as to not increase the pollution of the environment. Requirements for limitation of emissions of toxic compounds force to make design changes in engines, the use of modern and effective exhaust gas aftertreatment systems of the engine and improve the way of the operation of vehicles. The reduction of pollutant emissions and fuel consumption can also be achieved through the use of alternative fuels, including gas fuels, as well as their co-firing with conventional fuels. The article presents primarily the results of the exhaust emissions tests of railway vehicle, fuelled by B100. It has been shown differences in the concentrations of toxic compounds in the exhaust systems.

\section{Wykorzystanie paliw alternatywnych w pojazdach kolejowych}

\begin{abstract}
W ostatnich latach nastapił znaczny wzrost liczby ludności na świecie, a tym samym wzrost zapotrzebowania na transport. Aby sprostać temu zapotrzebowaniu, konieczny jest zrównoważony rozwój sektora transportu, tak aby nie zwiększać zanieczyszczenia środowiska. Wymagania co do ograniczeń emisji zwiqzków toksycznych wymuszajq wprowadzanie zmian konstrukcyjnych $w$ silnikach pojazdów, stosowanie nowoczesnych i skutecznych uktadów oczyszczania spalin silnika oraz poprawe sposobu użytkowania pojazdów. Redukcje emisji zanieczyszczeń $i$ zużycia paliwa można osiagnać także poprzez wykorzystanie paliw alternatywnych, w tym gazowych, jak również ich wspótspalanie z paliwami konwencjonalnymi. $W$ artykule przedstawiono przede wszystkim wyniki badań toksyczności spalin z pojazdu kolejowego, zasilanego paliwem B100 (tzw. biodiesel). Wykazano różnice w stężeniach toksycznych zwiazków w uktadzie wylotowym silnika.
\end{abstract}

\section{WPROWADZENIE}

Transport stanowi fundament każdej gospodarki, ponieważ leży u podstaw łańcucha dostaw. Rynek wewnętrzny nie może prawidłowo funkcjonować bez dobrych sieci transportowych. Inwestycje $w$ infrastrukturę transportu stymulują wzrost gospodarczy, tworzą majątek i usprawniają handel, poprawiają dostępność geograficzną i zwiększają mobilność ludzi. Stanowią też wysoce skuteczną siłę napędową w zakresie tworzenia nowych miejsc pracy. Dynamiczny rozwój transportu ostatnich dekad jest istotnym czynnikiem rozwoju gospodarczego świata i jednocześnie niestety znaczącym źródłem uciążliwości i problemów, istotnych szczególnie w skali lokalnej, zwłaszcza w dużych aglomeracjach miejskich. Niekorzystne

\section{INTRODUCTION}

Transport is the foundation of any economy, because it lies at the foundations of the supply chain. The internal market cannot function properly without a good transport network. Investments in transport infrastructure stimulates economic growth, creates wealth and enhances trade, geographical accessibility and mobility of people. They are also a highly effective driving force in the creation of new jobs. The dynamic development of transport of the last decades is an important factor of the world economic development and at the same time a significant source of nuisance and problems particularly relevant at the local level, especially in large urban areas. The negative effects of transport are felt by both the natural environment and 
skutki transportu odczuwa zarówno środowisko przyrodnicze, jak i społeczeństwo, któremu powszechny rozwój tego sektora umożliwił swego czasu przekroczenie istotnej bariery rozwoju cywilizacyjnego, przy czym efekty te różnią się w zależności od poziomu rozwoju gospodarczego, stopnia zaawansowania i wykorzystania różnych sektorów transportu, położenia geograficznego (w tym klimatu), a także wrażliwości elementów środowiska. Skala oddziaływania transportu kolejowego na środowisko i bezpieczeństwo jest nieporównanie mniejsza, aniżeli w transporcie drogowym. W Unii Europejskiej kolej realizuje 6,1\% całkowitego transportu pasażerskiego oraz $10,7 \%$ transportu towarowego $(17,1 \% \mathrm{w}$ transporcie wewnątrzwspólnotowym). Ze względu na dominację transportu drogowego za jeden z głównych celów Europejskiej Polityki Transportowej (EPT) uznano zwiększenie udziału alternatywnych form transportu - rewitalizację transportu kolejowego, promowanie transportu wodnego i rozwój transportu intermodalnego. Planuje się zwiększenie udziału kolei w przewozach pasażerskich do $10 \%$, a w towarowych do $15 \%$ do roku 2020. Dla porównania w Stanach Zjednoczonych kolej jest dominującą formą transportu towarowego $(45 \%$ udziału), podczas gdy w transporcie pasażerskim w zasadzie się nie liczy (niespełna 0,5\% udział w całkowitym bilansie transportu). Oddziaływanie transportu kolejowego na środowisko sprowadza się głównie do emisji hałasu i drgań, zanieczyszczeń (z lokomotyw spalinowych) oraz zajmowania terenu. Emisja zanieczyszczeń z transportu kolejowego w Unii Europejskiej jest rzędu 1-3\%.

Światowe zużycie energii przez transport wzrośnie w tempie około $2 \%$ rocznie i stanowi najwyższe tempo wzrostu w ostatnich dekadach. Całkowite zużycie energii i emisji dwutlenku węgla dla transportu wyniesie około $80 \%$ więcej od obecnego poziomu w roku 2030. W 2010 roku sektor transportowy produkował 7,0 Gt $\mathrm{CO}_{2}$, co stanowiło $14 \%$ światowej emisji $\mathrm{CO}_{2}$. Transport drogowy stanowi obecnie $72 \%$ całkowitej emisji $\mathrm{CO}_{2} \mathrm{w}$ transporcie, który jest główną przyczyna globalnego ocieplenia. Jak zostało to potwierdzone przez Międzyrządowy Zespół do spraw Zmian Klimatu, emisja $\mathrm{CO}_{2}$ pobudzi zmiany temperatury i klimatu (rys 1$)$.

W związku z wyczerpującymi się zasobami ropy naftowej oraz gazu prowadzi się badania nad paliwami alternatywnymi. Wprawdzie po części są one produktami przetwórstwa ropy naftowej, ale występują w dużej ilości, cechują się dobrymi technicznymi i energetycznymi właściwościami, są tanie $\mathrm{w}$ produkcji i sprzedaży, stanowią mniejsze zagrożenie dla środowiska naturalnego niż paliwa tradycyjne. Paliwa

Rys. 1. Globalny wzrost temperatury powierzchni Ziemi w funkcji całkowitej światowej emisji $\mathrm{CO}_{2}$ [2]

Fig. 1. The global increase of the surface temperature of the Earth as a function of total global $\mathrm{CO}_{2}$ emissions [2] the society, for which the general development of this sector has enabled exceeding the significant barriers to the development of civilization, the effects are different depending on the level of economic development, staging and use of the various transport sectors, geographical location (climate) and also the sensitivity of the environment. The scale of the impact of rail transport on the environment and safety is incomparably smaller than for road transport. In the European Union railways carried $6.1 \%$ of the total passenger transport and $10.7 \%$ freight transport (17.1\% when counted within the EU only). Due to the dominance of road transport one of the main objectives of the European Transport Policy (ETP) is to increase the share of alternative forms of transport the revitalization of rail transport, water transport and the promotion of intermodal transport development. The plan is to increase the share of rail passenger transport to $10 \%$ and cargo up to $15 \%$ by 2020 . For comparison, rail transport is the dominant form of freight transport in the United States (45\%), while passenger transport, in principle, does not count (less than $0.5 \%$ share in the total passenger transport). The impact of rail transport on the environment mainly comes down to noise and vibration pollution (from diesel locomotives) and land surface it occupies. Emissions from rail transport in the European Union are in the order of 1 ? $3 \%$.

World transport energy use is projected to increase at a rate of approximately $2 \%$ per year, with emerging economies accounting for the highest growth rate. Total transport energy use and carbon emissions are projected to be approximately $80 \%$ higher than current levels by 2030. In 2010, the transport sector produced $7.0 \mathrm{Gt} \mathrm{CO}_{2}$ emissions, accounting for $14 \%$ of world $\mathrm{CO}_{2}$ emissions. The growth rate of world transport energy use ranks the highest among the enduser sectors. Road transport currently accounts for $72 \%$ of total transport $\mathrm{CO}_{2}$ emissions, which is the leading cause of global warming. As confirmed by the Intergovernmental Panel on Climate Change, $\mathrm{CO}_{2}$ emissions spur temperature change and climate change (Fig. 1).

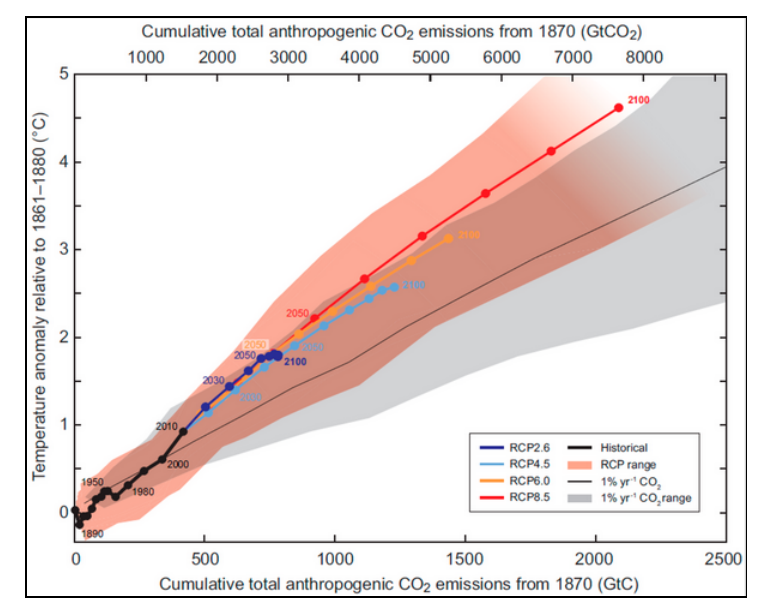


alternatywne w porównaniu z konwencjonalnymi paliwami ropopochodnymi (benzyna, olejem napędowym) posiadają trzy główne zalety $\mathrm{w}$ aspektach: niezależności energetycznej (można produkować $\mathrm{z}$ własnych surowców kopalnych i produktów rolnych), emisji (zmniejszenie emisji związków toksycznych) oraz kosztów eksploatacji (tańsze w zakupie). Dlatego też coraz powszechniejsze staje się ich stosowanie we wszystkich podjazdach spalinowych wykorzystywanych $w$ transporcie $[1,3,4]$.

\section{BADANIA LOKOMOTYWY ZASILANEJ PALIWEM B100}

Badania emisji składników szkodliwych przeprowadzono na oporniku wodnym $\mathrm{z}$ wykorzystaniem normalnotorowej lokomotywy spalinowej produkcji polskiej, oznaczonej jako SM42 (rys. 2a). SM42 to jednokabinowa, 4-osiowa lokomotywa o układzie osi Bo'Bo' z przekładnią elektryczną i elektropneumatycznym sterowaniem. Źródłem mocy jest silnik spalinowy z zapłonem samoczynnym oznaczony jako a8C22 o mocy $590 \mathrm{~kW}$ ( $800 \mathrm{KM}$; rys. 2b), którego producentem były Zakłady Cegielskiego w Poznaniu. Silnik ten posiada nietypowy dla silnika widlastego kąt rozwidlenia cylindrów wynoszący zaledwie 50 stopni. Kąt ten był podyktowany koniecznością uzyskania możliwie wąskiego silnika i całego przedziału silnikowego lokomotywy, celem zachowania widoczności z kabiny maszynisty. Silnik ten nie jest przez to dobrze wyrównoważony, przez co generowane są drgania. Silnik ZS napędza prąanice główną (prądu stałego), skąd prąd kablami płynie do szafy sterowniczej, a stamtąd do czterech silników trakcyjnych na wózkach (1 silnik na oś). Maszynista kręcąc nastawnikiem zmienia wzbudzenie wzbudnicy, co powoduje zmianę wzbudzenia prądnicy głównej i w efekcie zmianę napięcia na zaciskach prądnicy głównej. Regulacji mocy i prędkości obrotowej silnika spalinowego dokonuje regulator prędkości obrotowej Woodward przez zmianę dopływu ilości paliwa do cylindrów. Regulator Woodward wpływa też na proces wzbudzenia wzbudnicy.

a)

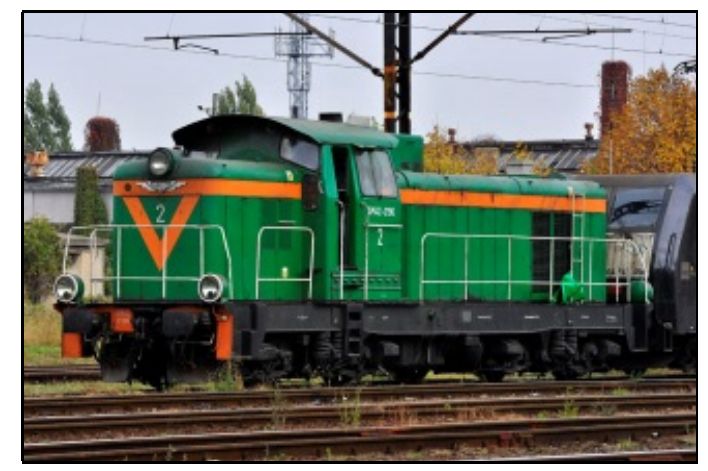

Rys. 2. Widok lokomotywy SM42 (a) oraz jej silnika a8C22 (b)
In connection with the exhaustible resources of oil and gas research on alternative fuels are carried out. Although they are products of oil processing but are abundant, characterized by good technical and energy properties, cheap in production and sales, and they represent a lower risk for the natural environment than the traditional fuel. Alternative fuels compared to oil fuels (gasoline, diesel) have three advantages: energy independence (you can produce your own halogenated fuels and agricultural products), emissions (reduction of toxic emissions), operating costs, and therefore becoming more common their application in all the driveways of combustion for transport $[1,3,4]$.

\section{THE RESEARCH OF LOCOMOTIVE FU- ELLED BY B100 FUEL}

Emission tests of harmful exhaust compounds were carried out on a water resistor using standard gauge diesel locomotive produced in Poland, marked as SM42 (Fig. 2a). SM42 is a single cabin 4-axle locomotive fitted with a Bo'Bo' axis system and an electric transmission and electro-pneumatic control. Its power source is an internal combustion ignition engine a8C22 with an output of $590 \mathrm{~kW}$ (Fig. 2b), produced by Cegielski Industries in Poznan. The engine has an unusual $\mathrm{V}$-angle of only 50 degrees. This angle was dictated by the need to achieve a narrow engine and the entire engine locomotive compartment, in order to maintain the driver visibility from the cabin. Hence this engine's mass is not well balanced, which causes vibrations to be generated. The diesel engine drives the main generator (DC), where current flows through the cables to the control cabinet, and from there to the four traction motors on the bogies (1 motor per axle). The driver by turning the adjuster changes the excitation of the alternator, which changes the main generator excitation and results in a change in voltage at the terminals of the main generator. Power and engine speed is regulated by the Woodward controller by the process of changing the amount of fuel flowing into the cylinders. Woodward regulator also affects the excitation of the alternator.

b)

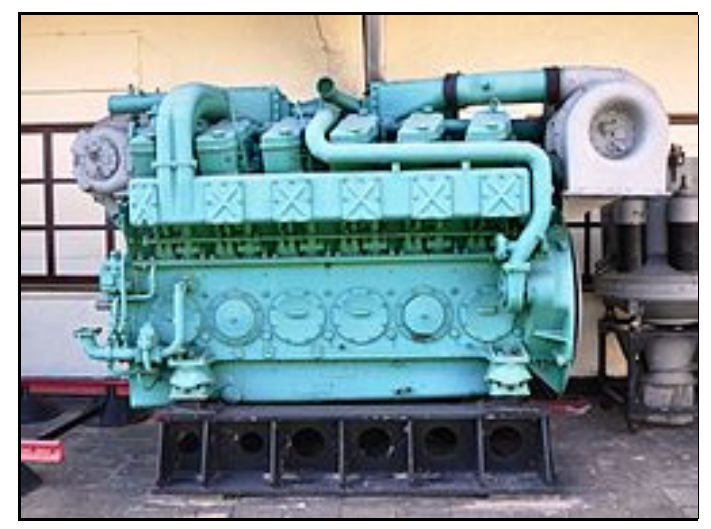

Fig. 2. SM42 locomotive (a) and its a8C22 internal combustion engine (b) 
Charakterystykę emisyjności silnika spalinowego wykorzystującego paliwo B100, oprócz badań emisji składników gazowych, uzupełniono o pomiary zadymienia spalin. Ze względu na większą gęstość oraz lepkość tego paliwa oczekiwano zwiększonego zadymienia spalin. Zmierzono zarówno zadymienie spalin $\mathrm{N}$ [\%], jak również współczynnik ekstynkcji $\left.\mathrm{k}^{-1} \mathrm{~m}^{-1}\right]$. Wyniki tych badań przedstawiono na rysunku 3 i 4 .

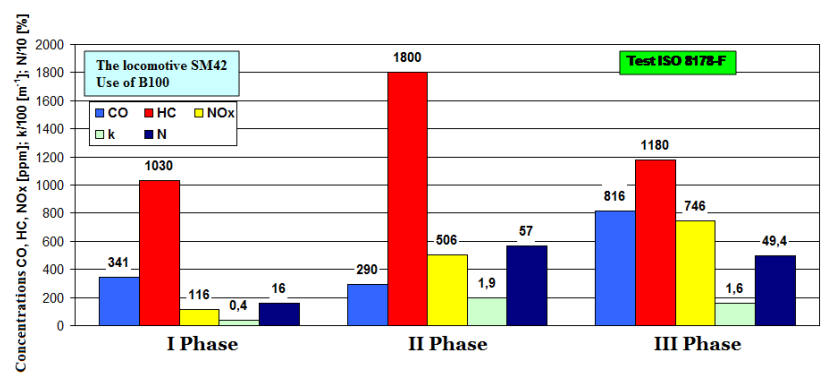

Rys. 3. Stężenie związków toksycznych i zadymienie spalin lokomotywy SM42-2331 zasilanej paliwem B100podczas faz testu ISO 8178-F

Fig. 3. The concentration of toxic compounds and smoke opacity of SM42-2331 locomotive powered with B100 fuel during ISO 8178-F test phases

Wartości emisji składników gazowych nie wskazują na niekorzystne oddziaływanie paliwa B100 na wskaźniki ekologiczne silnika. Niewielkie zmniejszenie emisji gazowych składników szkodliwych można by traktować jako potencjalne możliwości zastosowania tego paliwa do napędu silników pojazdów szynowych. Przemawiają za tym:

- zmniejszenie emisji $\mathrm{CO}_{2}$ przy produkcji tego paliwa,

- zmniejszenie nakładów energetycznych przy produkcji,

- wykorzystanie potencjału rolniczego obszarów kraju.

Limity normy ORE B13 nie wprowadzały pomiarów zadymienia spalin lub ekstynkcji. Zawierały natomiast normy dotyczące zaczernienia filtra pomiarowego - FSN (Filter Smoke Number). Metoda ta bazuje na pomiarach filtracyjnych, a nie jak obecne na pomiarach absorpcyjnych. $Z$ tego względu nie można mówić o prostych sposobach przeliczenia tych wartości. $Z$ tego powodu należało przeliczyć uzyskane wartości $\mathrm{N} \mathrm{i} \mathrm{k} \mathrm{na} \mathrm{FSN} \mathrm{na} \mathrm{podstawie} \mathrm{istniejących} \mathrm{tablic.}$

Korelację między zadymieniem spalin N [\%] (metoda absorpcyjna) a zaczernieniem filtra FSN (metoda filtracyjna) wykonano wykorzystując zależności firmy AVL (rys. 5). Zależność ta uwzględnia pomiary wykonane w firmie AVL oraz dwóch innych niezależnych laboratoriów na różnych silnikach spalinowych. Wyniki korelacji dotyczą badań wykonanych urządzeniami Smoke Meter AVL 415 oraz Opacimetr 438 oraz 439.
The emission characteristics of an internal combustion engine using the B100 fuel (pure biodiesel) was complemented by measurements of opacity in addition to testing the gaseous emissions. Due to the higher density and viscosity of the fuel an increase in opacity was expected. Both the density of the exhaust $\mathrm{N}[\%]$ and the extinction coefficient $\mathrm{k}\left[\mathrm{m}^{-1}\right]$ were measured. The results of these tests are shown in Fig. 3 and 4.

The values of gaseous emissions do not indicate adverse effects of the B100 fuel on engine environmental indicators. A slight decrease in gaseous emissions of harmful ingredients could be considered as potential use for this fuel in powering the engines of rail vehicles. The main reasons for its use are:

- a reduction of $\mathrm{CO}_{2}$ emissions in the production of this fuel,

- reducing the energy costs of manufacturing,

- effective use of the agricultural potential of the country.

Limits imposed by the ORE B13 emission standards did not introduce measurements of smoke opacity or extinction. They did. However, contain the standards for measuring the smoke in the filter - FSN (Filter Smoke Number). This method is based on a filtration measurements and not, as it is presently common, on an absorption measurement. For this reason, one cannot speak about simple ways of translation of these values in relation to each other. For this reason, a conversion from the obtained values of $\mathrm{N}$ and $\mathrm{k}$ into FSN had to be done based on existing tables.

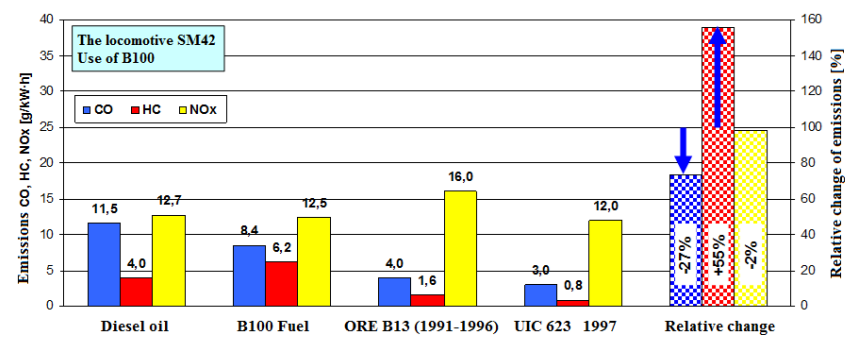

Rys. 4. Wartości emisji jednostkowej składników gazowych spalin lokomotywy SM42-2331 zasilanej olejem napędowym i B100

Fig. 4. The values of unit emission measurements of exhaust gas components in SM42-2331 locomotive fuelled by diesel oil and B100 fuel

The correlation between the smoke opacity $\mathrm{N}$ [\%] (absorption method) and smoke in the filter FSN (filter method) was performed using the relations provided by AVL (Fig. 5). This relationship takes into account measurements made in the AVL company and two other independent laboratories for a variety of internal combustion engines. The results of the performed correlation tests concern measurements performed with devices such as AVL Smoke Meter 415 and Opacimeters 438 and 439. 


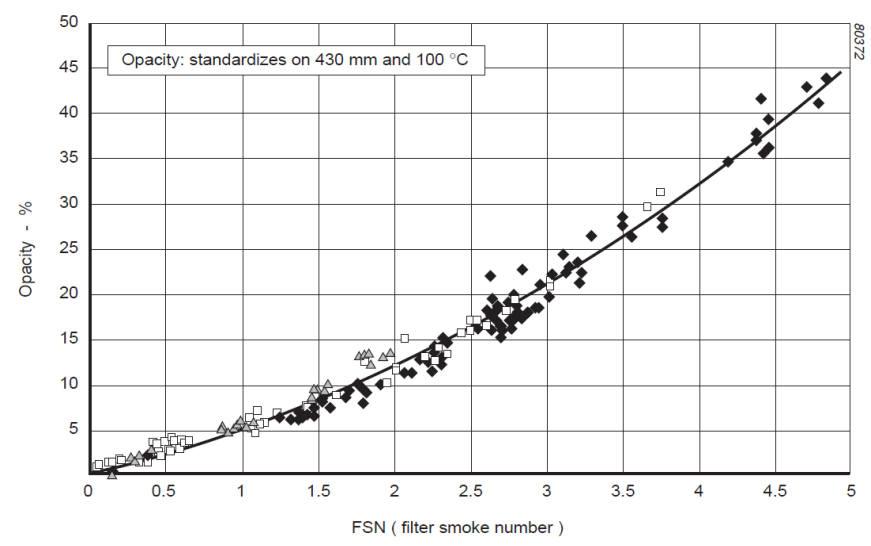

Rys. 5. Korelacja między zadymieniem spalin $\mathrm{N}$ a zaczernieniem filtra FSN [1]

Fig. 5. The correlation between the smoke opacity $\mathrm{N}$ and smoke in the filter FSN [1]

Wykorzystując krzywą zależności FSN i N oraz zależności dotyczące powiązania wielkości $\mathrm{k} \mathrm{i} \mathrm{N}$, określono zależności trzech wielkości dotyczących zadymienia spalin, co przedstawiono na rys. 6 :

$$
\mathrm{N}=100 \cdot\left(1-\mathrm{e}^{-\mathrm{k} \cdot \mathrm{L}}\right) ; \quad \mathrm{k}=\frac{-\ln \left(1-\frac{\mathrm{N}}{100}\right)}{\mathrm{L}}
$$

gdzie: $\mathrm{k}$ - współczynnik absorpcji [m $\left.{ }^{-1}\right]$; $\mathrm{N}$ - zadymienie spalin [\%], L - długość drogi pomiarowej $(\mathrm{L}=$ $0,43 \mathrm{~m})$.

$\mathrm{Na}$ podstawie wyników emisji dotyczących zasilania silnika lokomotywy SM42 paliwem B100 można stwierdzić, że:

- niskie wartości emisji jednostkowej $\mathrm{NO}_{\mathrm{x}}$ wynikają z niezupełnego i niecałkowitego spalania paliwa, czego przyczyny należy dopatrywać się $\mathrm{w}$ nieprecyzyjnej regulacji aparatury wtryskowej lub zużyciem elementów grupy tłokowocylindrowej. Za tym ostatnim przemawia bardzo duże zaczernienie spalin wyrażone we współczynniku

$\mathrm{k}\left[\mathrm{m}^{-1}\right]$,

absorpcji

- $\quad$ w celu ukazania stopnia zadymienia spalin dokonano pomiarów typowego zadymienia spalin (wyrażone współczynnikiem N) i przeliczono je na wartości limitowane przepisami,

norma ORE B13 podaje wartość dopuszczalną zaczernienia spalin na poziomie 1,6-2,5 wyrażoną w jednostkach FSN. Na podstawie powyżej zamieszczonej korelacji określono wartości cząstkowe FSN (dla każdej fazy badawczej), natomiast wartość końcową określono na podstawie udziałów faz. Wartość FSN wynosi około 3,6 - jest ona znacznie większa od limitów ORE B13.

\section{WYKORZYSTANIE CNG W LOKOMOTY- WACH}

Ilość paliwa zużywanego przez lokomotywy i
Using the curve relating FSN and N, and the dependence of the size relationship between $\mathrm{k}$ and $\mathrm{N}$, the relations between three figures for smoke opacity have been defined, as shown in Fig. 6:

where: $\mathrm{k}$ - absorption coefficient $\left[\mathrm{m}^{-1}\right] ; \mathrm{N}$ - exhaust smoke opacity [\%], $\mathrm{L}-$ measurement path length $(\mathrm{L}=$ $0.43 \mathrm{~m})$.

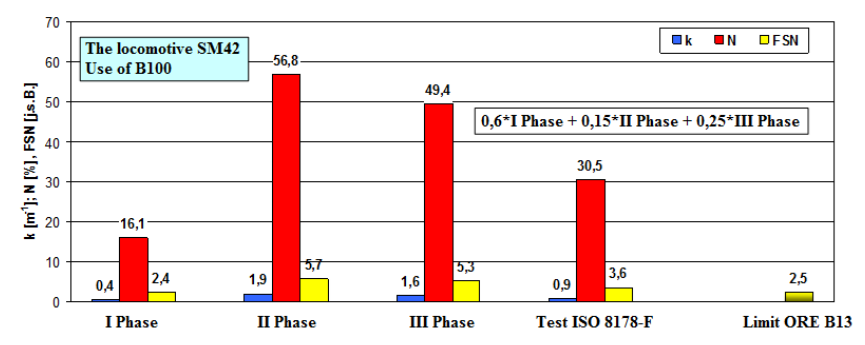

Rys. 6. Porównanie zadymienia spalin na tle normy ORE B13

Fig. 6. Smoke opacity compared to ORE B13 emission standards

Based on the emission test results for a SM42 class locomotive powered by B100 fuel it can be stated that:

- low specific $\mathrm{NO}_{\mathrm{x}}$ emission values system from partial or incomplete combustion of the fuel, caused by imprecisely regulated injection system or wear of the piston-cylinder group. The latter is given validation based on the very high smoke opacity as expressed in terms of the absorption coefficient $\mathrm{k}\left[\mathrm{m}^{-1}\right]$,

in order to demonstrate the degree of smoke opacity measurements of a typical smoke opacity (expressed in the coefficient $\mathrm{N}$ ) have been conducted, and converted into values as limited by the regulations,

the ORE B13 standard sets the limit of smoke opacity value at the level of 1.6? 2.5 expressed in FSN. On the basis of the described correlation partial FSN values were determined (for each phase of the research), and the final value was determined based on the shares of each of the phases. The FSN has a value of about $3.6-$ which is much higher than the ORE B13 limits.

\section{THE USE OF CNG IN LOCOMOTIVES}

The fuelling of railroad locomotives plays an important part in the economics of the railroad by virtue of the availability of fuel, the cost of fuel and the environmental effects of the fuel. During the days of the coal fired steam locomotives there were the drawbacks of smoke and dirty operation using coal plus the limited range of travel between water and fuelling stops. The diesel engine locomotive solved these problems but recent clean air studies (legislation are now threatening) diesel emissions, threaten the cost and availability of diesel fuel. These factors have led to the search for alternative fuels, including natural gas. 
wpływ procesu spalania tego paliwa na środowisko (emisja zanieczyszczeń) odgrywają ważną rolę w określaniu ekonomiczności i ekologiczności przewozów kolejowych. W czasach węglowych lokomotyw parowych głównymi problemami był dym i brudna praca, dodatkowo ograniczony był zasięg pojazdów przez konieczność zatankowania wody i uzupełnienia paliwa stałego. Lokomotywy z silnikami o zapłonie samoczynnym rozwiązała te problemy, ale ostatnio wykonywane badania dotyczące czystości powietrza (przepisy dotyczące zagrożeń płynących z emisji zanieczyszczeń) oraz stale prowadzone analizy gazów emitowanych z układów wylotowych silników ZS, powoli zaczęły zagrażać opłacalności i dostępności oleju napędowego. Powyższe uwarunkowania doprowadziły do intensyfikacji działań nad upowszechnieniem paliw alternatywnych, w tym gazu ziemnego.

Gaz ziemny spopularyzował się jako paliwo alternatywne $\mathrm{w}$ postaci sprężonej $(\mathrm{CNG}$ - Compressed Natural Gas) lub ciekłej (LNG - Liquefied Natural Gas). Dla pociagów ważne jest, aby mieć w zapasie wystarczającą ilość paliwa na długie przejazdy, stąd korzystniejsze jest stosowanie gazu w postaci skroplonej. W postaci cieczy przechowywać można około pięć razy więcej paliwa na pokładzie pojazdu niż w postaci CNG przy wysokim ciśnieniu, z równoważnymi wymogami przestrzennymi. Jednak w porównaniu z olejem napędowym LNG wymaga około dwukrotnie większej objętości dla równoważnej wartości kalorycznej paliwa, a co za tym idzie wymaga korzystania $z$ tendera na paliwo (patrz rozdział 4).

Mimo mniejszego zainteresowania CNG w kolejnictwie, spotyka się rozwiązania techniczne w tym zakresie. Przykładowo firma Rail Propulsion Systems oferuje innowacyjne technologie modernizacyjne od producenta Energy Conversion Inc., które umożliwiają niezawodne i efektywne zasilanie gazem ziemnym silnika klasycznej lokomotywy EMD (rys. 7 i 8). Układy zasilania firmy ECI są zoptymalizowane do bezpośredniego wtrysku gazu ziemnego pod niskim ciśnieniem (silnik ze zmodyfikowanym układem chłodzenia i tłokami). Zasilanie w układzie dwupaliwowym jest w pełni zautomatyzowane.

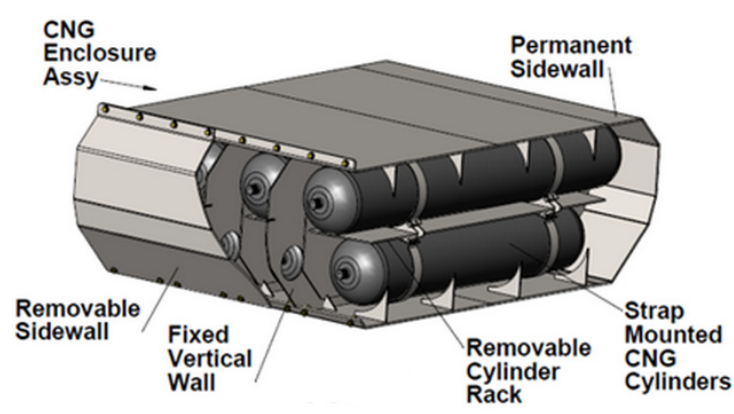

Rys. 8. System magazynowania CNG [5]
Natural gas has become a popular choice of many people as an alternative fuel, either as compressed natural gas $(\mathrm{CNG})$ or as liquid natural gas (LNG). For trains it is important to carry enough fuel for long runs and thus preferred is the use of liquefied gas. One can store approximately five times the amount of fuel on board a vehicle as a liquid compared with CNG at high pressure, with equivalent space requirements. When compared with diesel fuel however, LNG does require approximately twice the volume for the equivalent fuel value, thus necessitating the use of a tender car (see chapter 4).

Despite lower interest CNG in rail, the technical solutions in this area are found. For example, the company Rail Propulsion Systems offers innovative retrofit technologies from Energy Conversions Inc. that enable the classic EMD locomotive engine to operate reliably and efficiently on natural gas (Fig. 7 and 8). ECI's NG fuel systems are optimized direct low pressure gas injection with revised after cooling and modified pistons. Both dual fuel and dedicated gas conversions are available and provide fully automated operation, cleaner fuel, reduced engine wear and lower maintenance.

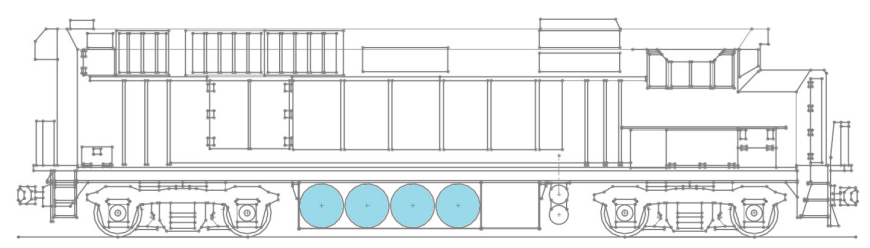

Rys. 7. Widok odpornego na ewentualne zderzenia systemu magazynowania gazu ziemnego [5]

Fig. 7. Crashworthy under frame natural gas storage system [5]

The described power system provides primarily:

- maintains diesel-only capability for greater versatility,

- achieves full rated horsepower in both diesel and dual fuel modes,

- less than $66 \%$ reduction in $\mathrm{NO}_{\mathrm{x}}$ emissions.

Dedicated natural gas CNG system also affects the $50 \%$ reduction in fuel costs, reduced PM emissions and meet higher emission standards.

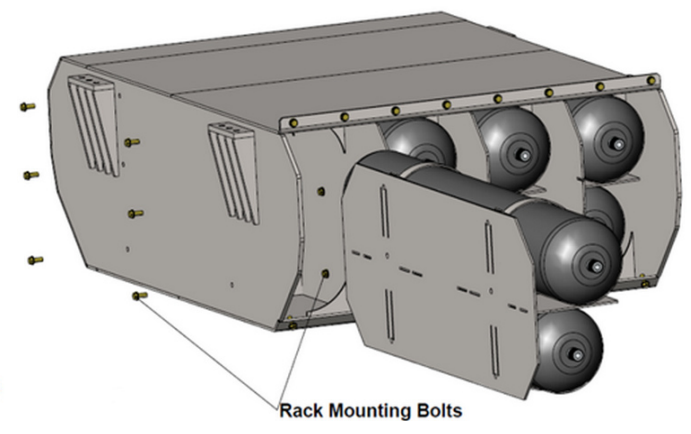

Fig. 8. CNG storage system [5] 
Opisywany system zasilania zapewnia przede wszystkim:

- utrzymanie silnika ZS w możliwie większej uniwersalności,

- osiaganie mocy znamionowej silnika dla obu systemów zasilania paliwem,

- redukcję o $66 \%$ emisji $\mathrm{NO}_{\mathrm{x}}$.

Dedykowany system gazu ziemnego CNG wpływa również na $50 \%$ zmniejszenie kosztów paliwa, zmniejszenie emisji PM oraz spełnienie wyższej normy toksyczności spalin.

\section{WYKORZYSTANIE SILNIKA HPDI W LO- KOMOTYWACH ZASILANYCH LNG}

Wspólnie z kolejami CN Rail, Electro-Motive Diesel (EMD) i Gaz Metro, firma Westport prowadziła prace nad projektem, który zaowocował efektywnym układem zasilania w paliwo LNG dla lokomotyw. Firma ta opracowała prototyp układu paliwowego, EMD zaprojektowało lokomotywę, $\mathrm{CN}$ podjęło się określenia opinii klienta oraz pomagało przy konstrukcji lokomotywy i tendera, natomiast Gaz Metro było odpowiedzialne za zapewnienie paliwa LNG. Poza aspektem projektu demonstracyjnego, silnik HPDI na skroplony gaz ziemny został sprawdzony laboratoryjnie przed instalacją w lokomotywie, gdzie osiagnął moc użyteczna, moment obrotowy i sprawność porównywalną z konwencjonalnym silnikiem ZS. Do spełnienia były też cele środowiskowe - silnik musiał spełnić amerykańską normę emisji Tier 3 lub wyższą (normy emisji Tier 4 zostały zatwierdzone w 2015 roku) oraz wykazywać mniejszą emisję gazów cieplarnianych o co najmniej $20 \% \mathrm{w}$ porównaniu do oleju napędowego.

Stopień sprężania silnika typu HPDI jest taki sam jak w silniku o zapłonie samoczynnym, na którego konstrukcji jest oparty, przez co zmniejszona została konieczność modyfikacji elementów silnika oraz zachowane zostały jego korzystne aspekty związane m.in. ze zużyciem paliwa i stosunkowo wysoką sprawnością. Silnik ten pracuje również w tym samym zakresie temperatury, co silnik o zapłonie samoczynnym, dzięki czemu nie wywiera dodatkowego obciążenia termicznego na elementy układu oraz nie wymaga modyfikacji układu chłodzenia. Układy elektroniczne zostały odpowiednio dostosowane aby umożliwić pełną integrację silnika HPDI w pojazdach poprzednio napędzanych silnikami ZS [6].

Technologia HPDI standardowo wykorzystuje cykl termodynamiczny silnika ZS, który ma większą sprawność, niż cykl termodynamiczny Otto wykorzystywany w silnikach spalinowych o zapłonie iskrowym. Dzięki zastosowaniu układu Dual Common Rail poprawiono kontrolę procesu spalania, niezawodność silnika, wydłużono okres eksploatacji jednostki i zmniejszono koszt produkcji.

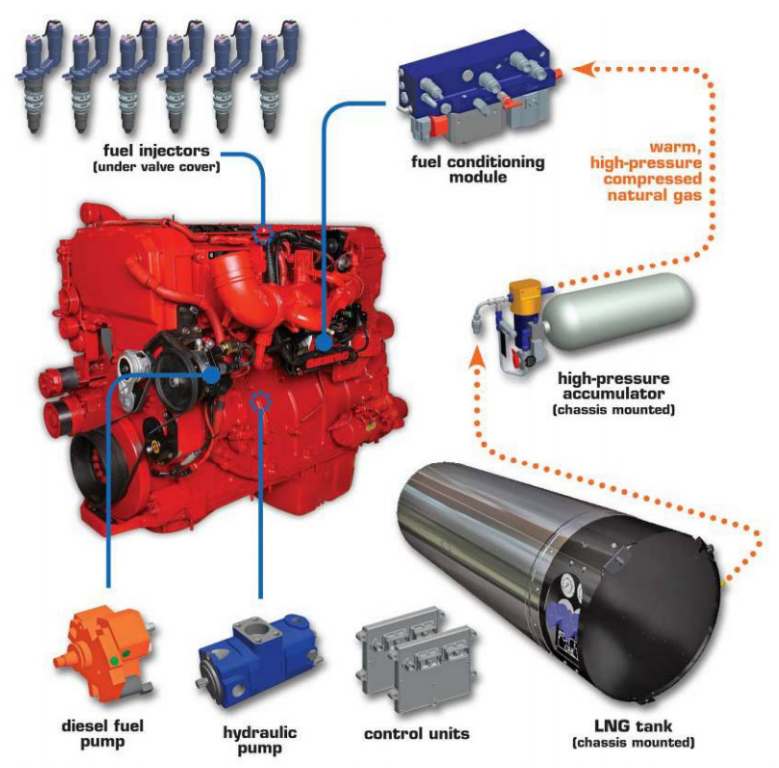

Fig. 9. Elements of HPDI system [6]

Rys. 9. Elementy układu HPDI [6]

\section{THE USE OF THE HPDI ENGINE IN LOCOMOTIVES FUELLED BY LNG}

Together with CN Rail, Electro-Motive Diesel (EMD) and Gaz Metro, Westport started work on a project that would deliver an LNG fuel system for locomotives. Westport developed the fuel system, EMD performed locomotive engineering, $\mathrm{CN}$ provided customer input and assisted with locomotives and tenders, and Gaz Metro was responsible for LNG fuel provision. More than just a demonstration project, the HPDI natural gas engine would need to be proven in a cell before installation in a locomotive; it would need to match diesel power, torque and efficiency. There were also environmental targets: the engine would have to meet U.S. Tier 3 emissions or better (Tier 4 emissions were mandated in 2015) and reduce GHGs by at least 20 per cent as compared to diesel.

The compression ratio in an HPDI type engine is the same as in a diesel engine, whose structure it is based upon, which reduced the need to modify engine components and maintained its preferred aspects relating to fuel consumption and high compression ratio. This engine also works in the same temperature range as the diesel one, so it does not exert additional thermal load on the system components and does not require modifications to the cooling system. Electronic systems have been adapted to allow for the full integration of the HPDI engine in vehicles previously powered by diesel engines [6].

The HPDI technology uses a standard thermodynamic cycle of CI engines, which has a higher efficiency than the Otto thermodynamic cycle used in SI internal combustion engines. By using the Dual Common Rail system the control and reliability were improved, along with extended unit service life and reduced engine cost. 
Większość obecnie stosowanych w rozwiązaniach mobilnych silników spalinowych zasilanych gazem ziemnym wymaga redukcji stopnia sprężania o nawet $30 \%$, wraz ze zmniejszeniem maksymalnej wartości momentu obrotowego o 15 ? 20\% w celu zmniejszenia ryzyka awarii silnika wynikającego z nadmiernego spalania stukowego, co dalej przekłada się na większe zużycie paliwa oraz mniejszą sprawność ogólną silnika. Bezpośredni wtrysk paliwa w późnej fazie cyklu pracy - będący cechą charakterystyczną konstrukcji silników Westport HPDI - jest jedynym rozwiązaniem dla procesu spalania eliminującym efekt spalania stukowego. W silnikach ZI zasilanych gazem ziemnym paliwo jest mieszane $\mathrm{z}$ powietrzem przed podaniem go do komory spalania. Stąd też silniki te potrzebują niższej wartości stopnia sprężania aby ograniczyć spalanie stukowe. Stopień sprężania musi być wystarczająco niski aby uniemożliwić występowanie zapłonu mieszanki przed zakończeniem cyklu sprężania i uruchomieniem świecy zapłonowej. Wiąże się to nieodzownie z mniej wydajnym procesem spalania oraz mniejszą sprawnością ogólną silnika, co oznacza konieczność spalenia większej ilości paliwa do wykonania tej samej pracy. Optymalizacja procesu spalania zmniejsza zużycie paliwa, co z kolei pozwala na szybszy zwrot kosztów inwestycji. W przypadku silnika HPDI firmy Westport sprawność w warunkach pracy wynosi ok. $44 \%$, gdzie typowe silniki ZI osiagają jedynie ok. $37 \%$. Oznacza to znacząca poprawę sprawności ogólnej jednostki napędowej, w tym znaczące zmniejszenie zużycia paliwa. Przykładowe porównanie charakterystyki konwencjonalnego silnika ZS z charakterystyką silnika z technologią HPDI zostało pokazane na rysunku 10 .

Silnik HPDI wykorzystuje gaz ziemny jako główne źródło zasilania, wraz z niewielkim dodatkiem oleju napędowego jako dawki zapłonowej. Te dwa paliwa nie są mieszane z powietrzem przed dostarczeniem ich do komory spalania, stąd zmniejszone zostało ryzyko wystapienia spalania stukowego silnika, a co za tym idzie zmniejszenie stopnia sprężania i maksymalnego momentu obrotowego nie jest konieczne. W porównaniu do oleju napędowego, bezpośrednio wtryskiwany gaz ziemny spala się w niższej temperaturze
Most internal combustion engines powered with natural gas currently used in mobile applications require a compression ratio reduction of up to $30 \%$, with a $15 \%$ to $20 \%$ reduction of the maximum torque to reduce the risk of engine failure resulting from excessive knock, which further results in increased fuel consumption and lower overall engine efficiency. The direct injection of fuel late in the cycle - which is common characteristic of Westport HPDI engine design - is the only combustion process solution for the elimination of knock. In SI and natural gas engines the fuel is mixed with air before it is delivered to the combustion chamber. Internal combustion engines powered by natural gas need to lower the compression ratio to reduce engine knock. The compression must be sufficiently low to prevent the occurrence of mixture ignition before the end of the compression stroke and before the spark of the ignition plug. This inevitably results in less efficient combustion and lower engine efficiency, which translates into the need to burn more fuel to perform the same job. Optimization of combustion process reduces fuel consumption allowing for a faster return on investment. In the case of the Westport HPDI engine the efficiency in standard operating conditions is approx. $44 \%$ where typical SI engines only achieve approx. $37 \%$, which means a significant improvement in the efficiency of the drive unit and a significantly reduced fuel consumption. Example performance curves for CI and HPDI engines are shown in Figure 10.

The HPDI engine uses natural gas as the main power source, together with a small amount of diesel fuel as the ignition dose. The two fuels are mixed with air before being delivered to the combustion chamber, which minimizes the risk of engine knock, and thus the compression ratio and maximum torque reduction is not necessary. In comparison to diesel fuel the directly injected natural gas is burnt in a lower adiabatic flame temperature, resulting in a lower tendency for the formation of carbon particles resulting in a reduction of toxic compounds production by lower emissions of nitrogen oxides and particulate matter. This is also managed by the additional gas dose control unit, to provide a further reduction. Recent HPDI engines

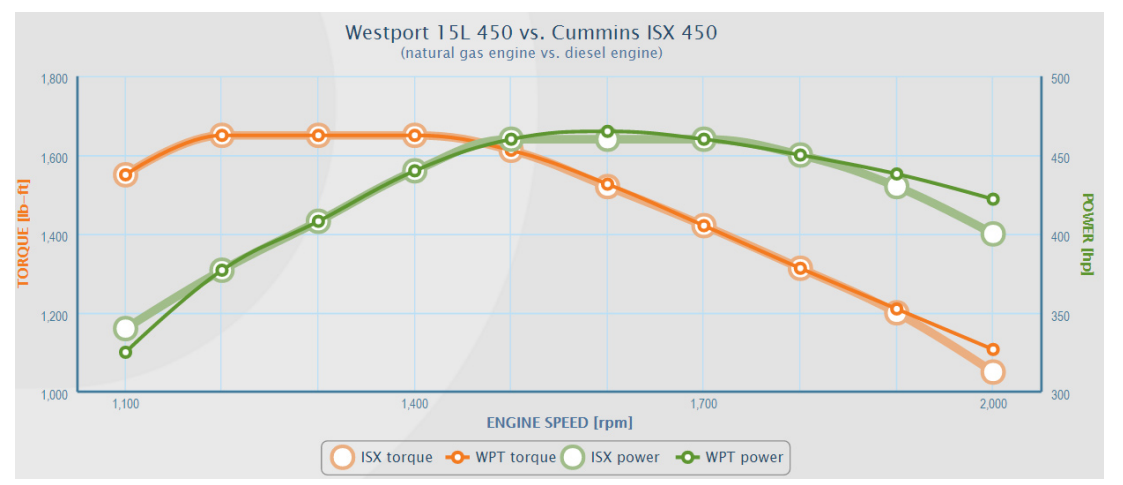

Rys. 10. Porównanie charakterystyk silników firm Wesport i Cummins [6] Fig. 10. Wesport and Cummins engine performance curves comparison [6]

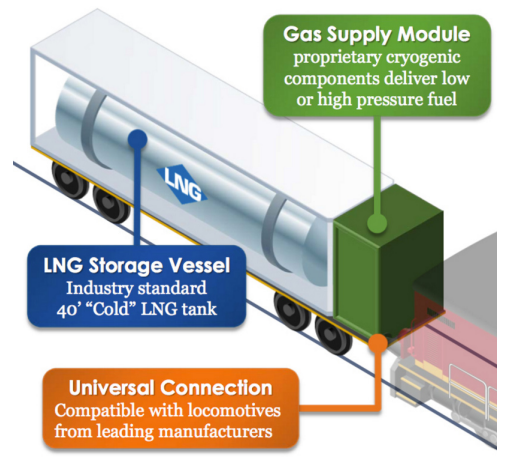

Rys. 11. Tender z LNG [6]

Fig. 11. The tender with CNG [6] 
płomienia adiabatycznego, czego efektem jest mniejsza tendencja do wytwarzania cząstek węgla. Uzyskuje się redukcję emisji związków toksycznych poprzez mniejszą emisję tlenków azotu oraz cząstek stałych. Kontroluje się to również poprzez dodatkowy układ sterowania dawką gazu ziemnego, uzyskując dalsze zmniejszenie emisji. Najnowsze silniki HPDI konstruowane są tak, aby spełniały obecne wymagania limitów emisji, zarówno Stage, jak i Tier. Jest to również jedyna dostępna na rynku technologia zasilania gazem ziemnym z możliwością kontroli emisji metanu wewnątrz cylindra, dzięki czemu możliwe jest uniknięcie kosztownych układów oczyszczania spalin z metanu. Wszystko to pozwala na większy zakres modyfikacji, umożliwiając projektantom układów napędowych zwiększenie sprawności układu a zarazem jego wartości w oczach konsumenta [6].

Przykładem zastosowania silnika HPDI jako zamiennika tradycyjnego silnika ZS o dużej mocy jest jego zastosowanie w lokomotywach. Wykorzystuje się silnik HPDI o parametrach bardzo zbliżonych do zastępowanego przez niego silnika ZS, dzięki czemu wymagane są jedynie drobne zmiany osprzętu, co zmniejsza koszt takiej przebudowy. Gaz ziemny przeznaczony do zasilania silnika HPDI, ponieważ stanowi 90\% dawki wykorzystywanego paliwa, przechowywany jest za lokomotywą w specjalnym tenderze pokazanym na rysunku 11 . Układ kontroli dawki LNG montowany jest również jako część tendera, dzięki czemu nie jest konieczne przeprojektowywanie rozkładu urządzeń w samej lokomotywie. Wykorzystuje on jednostopniową sterowaną hydraulicznie kriogeniczną pompe paliwową dzięki czemu tender można tankować ze stacji podających zimny gaz ziemny, co dalej poprawia zasięg pojazdu i zmniejsza koszty operacyjne stacji paliwowej. Umiejscowienie pompy bezpośrednio przy module zbiornika paliwa pozwala uzyskać maksymalny przepływ paliwa niezależnie od stopnia napełnienia zbiornika. Tender skonstruowany jest w taki sposób aby zapewnić możliwość współpracy i integracji dla wszystkich najpopularniejszych rozwiązań kolejowych, wykorzystywanych przez głównych producentów pojazdów szynowych. Możliwe są różne konfiguracje tendera, przez lub za lokomotywą. Przewidywana pojemność tendera na skroplony gaz ziemny to 10.000 galonów (prawie 38.000 litrów), dzięki czemu uzyskuje się duży zasięg lokomotywy. Jest to ważne, ponieważ dzięki takiemu rozwiązaniu operatorzy mogą uniknąć konieczności nadmiernej rozbudowy stacji tankowania gazu ziemnego lokomotywa $\mathrm{z}$ silnikiem HPDI wymaga tankowania rzadziej niż lokomotywa $\mathrm{z}$ konwencjonalnym silnikiem ZS o podobnej mocy. Wytworzone konstrukcje zbiorników paliwa oraz układy zasilania spełniają wszystkie wymogi bezpieczeństwa w Stanach Zjednoczonych oraz Unii Europejskiej. are designed to meet the current emission requirements, both the Stage and Tier. It is also the only commercially available technology with natural gas with the ability to control the emission of methane inside the cylinder, making it possible to avoid costly methane aftertreatment. All this allows for a greater range of modifications allowing designers to increase the system power transmission efficiency and also its value in the eyes of the consumer [6].

An example of the use of the HPDI engine as a substitute for traditional high power diesel engine is its application in a locomotive. HPDI engines are used with parameters very close to the replaced diesel engine, so only minor changes in equipment are required, which reduces the modernization cost. The natural gas supplied to the HPDI engine, since it represents $90 \%$ of the fuel dose used, is stored behind the locomotive in the special tender shown in Figure 11. The system that controls the dose of natural gas is also integrated as a part of the tender so that it is not necessary to redesign the device distribution in the locomotive. It uses a single-stage hydraulically controlled cryogenic fuel pump, so tender can refuel at station feeding it cold gas, which further improves the range of the vehicle and reduces the filling station operating cost. By placing the pump directly on the fuel tank module allows for maximum fuel flow regardless of the tank fuel level. The tender is constructed in such a way as to ensure the possibility of cooperation and integration for all popular rail solutions used by major rail vehicle manufacturers. It allows various configurations with the tender before or behind the locomotive. Expected tender fuel capacity for natural gas is 10000 gallons (nearly $38000 \mathrm{dm}^{3}$ ), which results in an increased locomotive range. This is important because with this solution, operators can avoid an excessive expansion of natural gas service stations, HPDI locomotive engine should require refueling less often than a diesel engine locomotive of similar power rating. The designed fuel tank and supply systems structures meet all safety requirements in the United States as well as in the European Union.

\section{SUMMARY}

Preventing the threats from transport from occurring, and when that is not possible - reducing the environmental impact and the scale and range of its negative effects, is an extremely important issue in the face of today's world. Appropriate action should be taken at different levels of government, local governments, as well as in the private sector. It is necessary to introduce appropriate legal and administrative regulations, the provision of adequate financial and human potential for the development of new technologies, special planning, rational design and infrastructure maintenance, as well as public education and management of transport tasks. 


\section{PODSUMOWANIE}

Niezwykle istotnym zagadnieniem $\mathrm{w}$ obliczu współczesnych zagrożeń płynących ze strony transportu jest zapobieganie ich występowaniu, a gdy nie jest to możliwe - ograniczanie ich presji na środowisko oraz skali i zasięgu negatywnych skutków. Odpowiednie działania powinny być prowadzone na szczeblach administracji rządowej, samorządowej, jak również w sektorze prywatnym. Niezbędne jest wprowadzanie właściwych regulacji prawnych $\mathrm{i}$ administracyjnych, zapewnianie odpowiednich środków finansowych i potencjału ludzkiego dla rozwoju nowych technologii, planowanie przestrzenne, racjonalne projektowanie $\mathrm{i}$ utrzymywanie infrastruktury, a także edukowanie społeczeństwa i racjonalizacja zadań transportu.

Spalinowy transport kolejowy i drogowy stwarzają znaczne ryzyko koncentracji zanieczyszczeń powietrza, zwłaszcza $w$ regionach $i$ centrach dużych miast. Stały wzrost liczby przemieszczających się pojazdów wymaga zmniejszenia powstających $\mathrm{w}$ procesie ich działania emisji związków szkodliwych. Jednym ze sposobów zmniejszenia emisji szkodliwych substancji jest wykorzystanie paliw alternatywnych. Jak już wspomniano ochrona środowiska jest obecnie najważniejszym wśród wielu czynników motywujących do stosowania biopaliw, które są paliwami odnawialnymi oraz corocznie zmniejszają emisję dwutlenku węgla i dwutlenku siarki, głównych składników powodujących degradację atmosfery - efekt cieplarniany i kwaśny deszcz. Ponadto obserwuje się ich korzystny wpływ na redukcje emisji toksycznych składników spalin.

Przedstawione w artykule wyniki badań i dokonane analizy literatury potwierdzają słuszność przyjętego kierunku rozwoju systemów napędowych pojazdów kolejowych i drogowych. Paliwa alternatywne w zakresie ich właściwości ekologicznych w niektórych aspektach przewyższają konwencjonalny olej napędowy. Również pod względem parametrów użytkowych, właściwości jezdnych i operacyjnych, pojazdy napędzane paliwami alternatywnymi w pełni spełniają stawiane przed nimi oczekiwania. Wyniki badań są motywacją do dalszych prac mających na celu opracowanie alternatywnych sposobów zasilania pojazdów transportu kolejowego. Dlatego kierunki dalszych prac badawczo-rozwojowych powinny dotyczyć między innymi oceny wpływu paliw alternatywnych na trwałość systemów oczyszczania spalin zainstalowanych w pojazdach szynowych.
Rail and road transport, especially in the regions and centres of large cities, creates significant risks of concentration of air pollutants. Constant increase in the number of moving vehicles will need to reduce emissions produced in the process of their operation. One way to reduce harmful emissions is the use of alternative fuels. As already has mentioned among the many reasons the environmental protection is now the most important factor motivating the use of biofuels, which are renewable fuels and annually reduce carbon and sulfur dioxide emissions, the main ingredients that cause degradation of the atmosphere - the greenhouse effect and acid rain. Furthermore, their beneficial effects on toxic exhaust emissions are observed.

Conducted under this article tests and made analysis of the literature confirm the validity of the adopted towards of the propulsion systems development of rail and road vehicles. Alternative fuels in terms of their ecological properties in some aspects surpass conventional diesel oil. Also in terms of driveability and operating parameters, the vehicles powered by alternative fuels fully meet the placed expectations. Therefore, the directions of further research and development works should concern, among other things, the evaluation of the impact of alternative fuels on the durability of exhaust aftertreatment systems installed in rail vehicles.

\section{BIBLIOGRAFIA}

[1] O. Edenhofer, R. Pichs-Madruga, Y. Sokona, C.J. Minx, E. Farahani, S. Kadner, K. Seyboth, A. Adler, I. Baum, S. Brunner, et al, Eds., "Working Group III Contribution to the Fifth Assessment Report of the Intergovernmental Panel on Climate Change", Intergovernmental Panel on Climate Change: Cambridge, UK, New York, NY, USA, 2014.

[2] J. Merkisz, P. Lijewski, P. Fuc, J. Pielecha, "Exhaust emission tests from agricultural machinery under real operating conditions”, SAE 2010 Commercial Vehicle Engineering Congress, October, Chicago, IL, USA, SAE Paper 2010-01-1949, 2010.

[3] J. Merkisz, P. Fuc, "The Exhaust Emission from Light Duty Vehicles in Road Test in Urban Traffic", SAE Technical Paper Series 2010-01-1558, 2010.

[4] T. Stocker, D. Qin, G.K. Plattner, M. Tignor, S. Allen, J. Boschung, A. Nauels, Y. Xia, V. Bex, P. Midgley, Eds., "Climate Change 2013: The Physical Scientific Basis. Contribution of Working Group I to the Fifth Assessment Report of the Intergovernmental Panel on Climate Change", Intergovernmental Panel on Climate Change: Cambridge, UK, New York, NY, USA, 2013.

[5] Materials of Rail Propulsion Systems: www.railpropulsion. com.

[6] Materials of Wesport: http://www.westport.com. 